Araştırma Makalesi

\title{
Wolverine (2013) Filminin Tekno- Oryantalizm Bağlamında İncelenmesi
}

\author{
Rifat Becerikli (Dr. Öğr. Üyesi) \\ Yozgat Bozok Üniversitesi Illetişim Fakültesi \\ beceriklirifat@hotmail.com
}

Başvuru Tarihi: 21.04.2020

Yayına Kabul Tarihi: 17.06.2020

Yayınlanma Tarihi: 24.07.2020

https://doi.org/10.17680/erciyesiletisim.724560

\section{Öz}

Edward Said genel olarak, Batılı toplumların Doğu ülkeleri üzerindeki güç ve iktidar oluşturmak için kullandığı hegemonik ilişkilerin bütününü oryantalizm olarak tanımlamaktadır. Zaman içinde oryantalizm düşüncesi çeşitli biçimlere evrilerek farklı coğrafyalarda yeniden tanımlanmıştır. Bu bağlamda son yıllarda özellikle Amerika Birleşik Devletleri'nin başta Japonya olmak üzere Doğu Asya ülkeleri üzerinde kurmaya çalıştığı hegemonik ilişki biçimine tekno-oryantalizm adı verilmektedir. Tekno-oryantalizm düşüncesinin genel olarak bilimkurgu filmlerinde görünür olduğu bilinmektedir. Özellikle Hollywood filmleri Batılı egemen düşüncenin oluşturulmasında ve yayılmasında başat faktörlerden biridir. Bu bağlamda çalışmada dünya çapında en çok izlenen ve filmin neredeyse tamamı Japonya'da geçen The Wolverine eseri örneklem olarak seçilmiștir. Araştırmada betimsel film analizi yöntemi kullanılmıştır. Çalıșmanın amacı tekno-oryantalizm bağlamında filmsel evrendeki görünmez kodları ortaya çıkararak zımni olarak yer alan Batılı iktidar ve güç ilişkisini ortaya çıkarmaktır. Sonuç olarak filmin anlatısında tekno-oryantalist bakış açısıyla yaratılan Wolverine karakterinin Batılı zihinde ekonomik ve teknolojik olarak yükselen Japonya ve Doğu Asya tehdidini gidererek Batılı seyirciyi rahatlatmaya çalıştığı ortaya çıkmaktadır.

Anahtar Kelimeler: Sinema, Tekno-Oryantalizm, Oryantalizm, Hollywood Filmleri. 


\title{
An Analysis of The Wolverine (2013) in terms of Techno-Orientalism
}

\author{
Rifat Becerikli (Asst. Prof. Dr.)
}

iD Yozgat Bozok University Faculty of Communication beceriklirifat@hotmail.com

Date Received: 21.04.2020

Date Accepted: 17.06.2020

Date Published: 24.07.2020

https://doi.org/10.17680/erciyesiletisim.724560

\section{Abstract}

Edward Said generally explains the whole hegemonic relations, which Western societies use to dominate Eastern countries, as orientalism. In the course of time, orientalism has evolved into several forms and it is redefined in different geographies. In this context, the form of hegemonic relationship, which the United States has tried to establish in East Asian countries (particularly Japan) in recent years, is called techno-orientalism. It is known that techno-orientalism is generally seen in science fiction films. Hollywood films are particularly one of the main factors in the creation and distribution of Western hegemony. In this sense, The Wolverine, which is the most watched movie in the world and entire film is set in Japan, was selected as a sample. Descriptive film analysis method was used in the study. The aim of the study is to indicate the implicit relation of Western domination by revealing invisible codes in the film universe in terms of techno-orientalism. As a result, it is revealed that the Wolverine, who is created with a techno-orientalist viewpoint in the film's narrative, tries to relieve Western audience by eliminating the threats; Japan and East Asia that develop economically and technologically in Western mind.

Keywords: Cinema, Techno-Orientalism, Orientalism, Hollywood Movies. 


\section{Giriş}

Zamanın egemen düşünce biçimleri insanları, devletleri veya kültürleri kendi bakış açılarına göre tanımlama girişiminde bulunur. Edward Said'den itibaren oryantalizm düşüncesi temelinde kitaplar, resimler, filmler incelenmeye başlanır. $\mathrm{Bu}$ bağlamda Batı'nın Doğu halkları, kültürleri üzerinde bir hâkimiyet ve iktidar kurma biçimleri ortaya çıkarılmaya çalışılır (Yavuz, 1998, s. 70). Said, Batılı zihnin Doğu hakkındaki oryantalist düşüncelerini ifşa ederek hegemonik ilişkilerde yeni bir evre açar. Her şeyden önce Batı, Doğu’yu “öteki” olarak görmektedir. Oryantalizm farklılıklar üzerine kurulmuştur; insan düşüncesini "Doğu" ve "Batı" olmak üzere iki bölüme ayırır (Said, 1998, s. 72). Bu bağlamda oryantalizmin temeli "biz-onlar" düalizmine dayanır (Konty, 2002, s. 117). Biz "Batı" ve onlar "Doğu" şeklindeki bu tanımlama aslında ekonomik, siyasi ve kültürel kazançlar için yaratılır. Diğer bir ifade ile oryantalizm coğrafi bir ayrım değildir bir seri "çıkarlar" toplamıdır (Said, 1998, s. 26). Batılı zihin çıkarları içinse birçok argüman kullanabilmektedir. Oryantalizm bilimsel keșifler, filolojik çalışmalar, psikolojik analizler, manzara tarifleri ve sosyolojik açıklamalarla ayakta tutulmaya çalışan bir yapıdır (Said, 1998, s. 26). Bu çalışmalar olmadan oryantalizmin devam etmesi zor görünmektedir. Aslında Doğu ve Batı arasındaki ilişki her şeyden önce bir güç ve üstünlük ilişkisidir (Said, 1998, s. 17). Burada hakimiyet kurmak isteyen ise Batı'dır. Said oryantalizmi, “Batı'nın Doğu'ya üstünlük sürdürme taktiği, Doğu üzerinde otorite kurma çabası" (1998, s. 14) olarak belirtir. Öte yandan oryantalizm bir bilgi üretme ve bilgiyi hegemonize etme modeli olarak da temellendirilebilir (Kahraman, 2002, s. 156). Bu bağlamda oryantalizm özellikle kültürel hegemonya aracılığı ile ayakta kalır (Said, 1998, s. 279). Diğer bir ifade ile oryantalizm estetik, bilimsel, ekonomik, sosyolojik, tarihe ait ve filolojik metinler aracılığı ile "aktarılmaya" çalışan bir cins jeo-ekonomik görüşler bütünüdür (Said, 1998, s. 26). Aynı şekilde oryantalizmi ya da oryantalist görüşleri birçok farklı metinde değişik biçimlerde görmek ve ortaya çıkarmak mümkündür. Günümüzde ise kitle iletişim araçları farklı düşünce biçimlerini, çeşitli yöntemlerle insanları etkilemek için kullanır. Buradaki amaç Batının üstünlügünü vurgulamak, bu üstünlügün dünyanın geri kalan bölgelerine yayılmasının gerekli olduğuna diğerlerine inandırmaktır (Boztemur, 2002, s. 135).

Batılı zihnin temel sorunu ise Doğunun ve Doğulunun sunumunda ortaya çıkar. “Doğu, açık seçik ve nutuklarda yer aldığı șekli ile ve Batı'nın takdimi ile ortaya çıkar" (Said, 1998:39). Doğu'nun özelliklerini belirleyen Batı olmaktadır. Batı'nın tasnifi ve sınıflandırma ölçütlerine göre Doğu betimlenmektedir. Bu açıdan oryantalizmde Batı ötekine karşı, uygarlaştırıcı bir misyon yüklenir (Boztemur, 2002, s. 135). Batı, Doğuya bir takım özellikler atfeder. Bunların en belirgini Batının ya da Batılının zihin dünyasına göre diğer herkes özellikle de Doğu dünyası durağan ve türdeş (homojen), Doğulu insanlar ise her yerde aynı olarak temsil edilir (Çırakman, 2002, s. 184). Bu bağlamda oryantalizm Batılı modern benliğin nasıl farklı olanı ötekileştirerek (Batı-dışı olanı) kurulduğunu tarihsel ve söylemsel olarak çözümler (Keyman, 2002, s. 21).

Batı'nın oryantalist söylemi uzun yıllardan beri Doğu Asya üzerinde etkilidir. Japonya'nın kabaca Meiji Döneminden beri (1868-1912), Batı'nın oryantalist söylemiyle modernleştiği söylenebilir (Binark, 1998). Aynı şekilde Güney Kore'de özellikle 2. Dünya Savaşı sonrası modernleşme, Batılılaşma ve Amerikanlaşma ile eşdeğerdir; Amerikan tüketim malları ve popüler kültür ürünleri temelli bir modernleşme görülmektedir (Jeong, 2011, s. xii). 1953'te kişi başına geliri 60 dolar olan Güney Koreliler umutsuzca fakirdir (Klein, 2020, s. 17). Amerika yardımları ve destekleri Güney Kore'nin kapitalistleşme sürecinde başat faktör olarak yer alır (Klein, 2020). Aslında Amerika, Çin ve Rusya etkisinden kurtarmak 
için birçok Doğu Asya ülkesine yardım eder. Güney Kore, Japonya, Tayvan, Filipinler, Tayland, Güney Vietnam, Laos, Kamboçya gibi ülkelere milyarlarca dolar diş yardım döker. Bunu yaparken Amerikan mallarını ihraç ederek, Asya'nın hammaddelerinin ithalatını sağlar ve özel kurumsal genişlemeyi teşvik edip ekonomik varlığını artırır (Klein, 2003, s. 26). Klein, 2. Dünya Savașı sonrası bu döneme "soğuk savaș oryantalizmi" adını verir (Klein, 2003). Diğer bir ifade ile Doğu Asya'nın günümüze değin gelişmesinin etkenlerinden biri olarak Amerika'nın oryantalist faaliyetlerinin de katkısı bulunmaktadır.

\section{Klasik Oryantalizmden Tekno-Oryantalizme}

Tekno-oryantalizm $^{1}$ temel dayanaklarını Edward Said'in oryantalizm kavramsallaştırmasından oluşturur. Batı ve Doğu arasında yüzyıllardır süren iktidar ve güç ilişkisine sosyal medya, bilgisayar oyunları, internet, siber ağlar vb. teknoloji temelli yeni bakış açısını da resmetmektedir. Bu bağlamda Said'in görüşlerini temel bağlamda klasik oryantalizm olarak adlandırmak daha doğru görülmektedir.

Oryantalist düşünürler tarafından Doğu konusunda ortaya konmuş fikirlerin Batı'nın politik çıkarlarına yaraması mümkündür (Said, 1998, s. 141). Tekno-oryantalizm de aynı şekilde Batı'nın siyasi ve ekonomik kaygıları nedeniyle Doğu Asya ülkelerini kendi çıkarları için yönlendirme amacındaki düşünceler sistematiğidir. Said genel olarak Avrupa'nın, Ortadoğu ve İslam coğrafyasındaki oryantalist düşüncelerini vurgularken öngörü olarak Amerika'nın Doğu Asya ülkeleri üzerindeki olası oryantalist amaçlarını da açıkça ifade eder. Avrupa'nın Doğu üzerindeki emperyalist fikirleri ile Amerika'nın Uzak Doğu ve Yakın Doğu hakkındaki emperyalist fikirleri arasında paralellik bulunmaktadır (Said, 1998, s. 400). Bu bağlamda tekno-oryantalizmin fikri temelleri zaten Batı'nın zihin dünyasında uzun yıllardır bulunmaktadır. Doğu Asya toplumları, Batı'nın gözünde silahlı gücü temelinde korku duyulan kimselerdir; örnek olarak "Sarı Tehlike Çin" ve "İstilacı Moğol Sürüleri” verilebilir (Said, 1998, s. 408). Ancak günümüzde durum değişir klasik Batı oryantalizmi, Doğu Asya'dan artık teknolojik ve ekonomik ilerlemesi nedeniyle korkmaktadır.

Oryantalizm Doğu'nun ve Doğulu'nun geriliği üzerine vurgu yapmaktadır (Said, 1998, s. 142). Tekno-oryantalizmde ise Doğu Asya ve özellikle Japonya'nın teknolojik ilerlemesi bir kötülük kaynağı olarak vurgulanır. Klasik oryantalizm fikrinde Batı modern olan, gelişmiş olandır. Oryantalizm Doğu'yu karanlıklardan kurtaran bir kahraman gibidir; Doğu'yu çağdışıllktan çekip çıkarmak isteyendir (Said, 1998, s. 144). Bu bağlamda oryantalizm, Batı'nın Doğu üzerindeki üstünlüğü ile eş değerdir (Said, 1998, s. 271). Tekno-oryantalizmde Batı'nın üstünlüğünün tersine bir süreç vardır. Tekno-oryantalizm Japonya'nın başarılı modernleşmesinin bir ispatıdır (Nihei, 2009, s. 88). Hatta birçok kimseye göre Japonya'nın Batı modernitesini de aşacak bir gelecek beklemektedir (Morley ve Robins, 1995, s. 149). Bu gelişim çizgisi de temelde Batı'yı korkutur. Aynı şekilde Batı kültürel hegemonya kuramayacağı gibi teknoloji ve mal satıp kâr elde edemeyecek ve kendisi Japonya ya da Doğu Asya tarafından yaratılan yeniliklerin pazarı olacaktır (Morley ve Robins, 1995, s. 168). Bugüne kadar Batılı zihnin alıșık olmadığı bir süreç yaşanmaktadır. Öte yandan Doğu ve Batı arasındaki ilişkiler Batılıların önüne geçilmez pazar arayışları ile yeniden düzenlenir; sürekli yeni kaynaklar, yeni koloniler aranır (Said, 1998, s. 140). Tekno-oryantalizm aslında Japonya temelinde Doğu Asya ülkelerinin hâkimiyetinin kabulü ve bunu tersine çevirmeyi amaçlamaktadır. Aynı şekilde klasik oryantalizmin aksine Batı'nın pazar olmaması için hazırlanan düşünceler toplamıdır. Bu açıdan klasik oryantalizm, Batı'nın Doğu üzerinde yönetme isteği olarak düşünülebilir (Said, 1998, s. 140). Tekno-oryantalizm ise Batı'nın, Doğu Asya'yı 
hegemonya üzerinden yönetemediğinin bir dışavurumudur. Ancak tekno-oryantalizm aynı zamanda Batı'nın Doğu Asya ülkelerini gelecekte yönetmek için yaptığı bir ön hazırlık olarak da değerlendirilebilir. Aslında tekno-oryantalizm, klasik oryantalizm düşüncesi gibi, modernlik projesine büyük önem verir (Roh, Huang ve Niu, 2015, s. 3). Japonya ve Doğu Asya ülkelerinin aynı Batı gibi modernleşmesi olumlu olarak sunulmaktadır. Batı'yı burada tedirgin eden ise Doğu Asya ülkelerinin özellikle teknoloji ve ekonomi alanında kendilerine rakip olması hatta bazı nitelikler özelinde kendilerini geçmeleridir. Teknolojik ve gelecek hayal gücü Asya temelinde artık Japonya'da merkezileşir; modernleşmenin soyut ve evrenselleştirici gücü Avrupa'dan Amerika'ya ve oradan da Japonya'ya geçer (Morley ve Robins, 1995, s. 153). Bu dünyayı şekillendirecek modernleşme merkezinin Doğu Asya'ya kayması Batılı zihni tedirgin eder çünkü modernleşmenin teknoloji temelinde yeni sürdürücüsü Japonya olacaktır. Geçmişten itibaren kendilerini mutlak bir sanayi, kültür ve dünyanın geri kalanından ileride oldukları fikri ile bağlı olan Avrupa ve Amerika artık geriye düşer.

Japonya teknolojik olarak bu noktaya hemen ulaşmaz. 2. Dünya Savaşı'ndan bu yana Japonya, dünyadaki diğer tüm uluslardan daha fazla teknolojik ilerleme yaşar (McLoad, 2013, s. 260). Japonya, kömür ve çelikten gemi yapımı, ağır makinelere ardından elektronik ve bilgisayarlara, makine ve yarı iletkenlerin ardından robot ve biyoteknolojiye geçiş yapar (Woronoff, 1996, s. 72). Böylece dünya savaşından yenilgi ile ayrılan Japonya tümden bir kalkınma hamlesi içindedir. Gelecek zaman içinde özellikle Çin'in hem teknolojik ürünlerinin yaratımında hem de üretiminde daha önemli yerlere gelmesi de beklenmektedir. Bu bağlamda akıllı telefon pazarında 2019 yılında dünya genelinde yaklaşık olarak Samsung 300, Apple 240, Huawei 200, Xiaomi 125, Oppo 120 milyon adetlik satışa ulaşır (Soni, 2020). Teknolojik olarak akıllı telefon pazarı dünyada giderek genişlemektedir. Bu bağlamda dünyada en çok cep telefonu satan beş şirketin dördü Asya kökenlidir

Son yıllarda tekno-oryantalizm ile bağlantılı olarak neo-liberal düşünce de öne çıkmaktadır. Doğu ile Batı arasında daha fazla bilgi ve sermaye akışı sağlayan neoliberal ticaret politikalarının ardından Asyalaştırılmış bir geleceğin tekno-oryantalist spekülasyonları daha da yaygınlaşır (Roh, Huang ve Niu, 2015, s. 2). Bu durum da globalleşme ve küresel kapitalizm ile yakından ilgilidir. Yeni pazar arayıșı teknoloji gelişiminin en başat faktörüdür. Şirketler satış yapabilmek ya da satışlarını arttırabilmek için geliştirdikleri teknolojilerinin piyasa tarafindan standart bir ölçüt olarak kabul edilmesini beklemektedir. Tekno-oryantalizm, kapitalizm/tüketim kültürü ile teknoloji arasındaki yakın ilişkiden doğar (Niu, 2008, s. 74). Kapitalizm ve tüketim kültürü devamlı bir yaratım ve bu yaratımın mal, hizmet ürününe dönüşüp satışı sonucu kâr elde etme ve yeniden yaratıcı ürünlere döndürmeyi amaçlar. Niu'ya göre Çin, Japonya ve diğer Doğu Asya ülkeleri teknolojik yaratım ve üretim sürecinde başarılıdır, birçok Asyalı Batı'daki teknolojik şirketlerde istihdam edilmektedir (2008, s. 76). Yakın zamandaki rekabet televizyonlardaki Led teknolojisinde görülür. Lg firması Oled ve Samsung firması Qled panel teknolojisi ile Güney Koreli iki rakip firmadır. Seksenli yıllarda ise, Japon tüketici elektroniği ürünleri Batı hanelerinde önemli bir varlık kazanır (Lozano-Méndez, 2010, s. 187). Bu yıllarda Jvc firmasının Vhs ve Sony firmasının Betamax arasında videokaset rekabeti iki Japon firması arasındadır hemen ardından Toshiba firmasının hd-dvd ile Sony'nin blu-ray diskleri arasında yaşanan rekabet bulunmaktadır. İki Japon şirketi Nintendo ve Sega, 1980'lerden itibaren video/bilgisayar oyun pazarına hükmederlerdi, ancak Sony 1994 yılında Play Station ile piyasaya girdiğinde, halka açık bir konsol savaşı 
başlattığı görüldü (Cornea, 2007, s. 195). 2019 rakamlarına göre yaklaşık olarak Play Station-4 107 milyon, Nintendo Switch 51 milyon, Microsoft X-box One 47 milyonluk satış rakamlarına ulaşır (D’Angelo, 2020). Bu açıdan iki Japon şirketin video konsol pazarında bir üstünlüklerinin olduğu görülmektedir.

İncelendiğinde 1980'li yıllardan günümüze teknolojik alanda rekabet eden firmaların daha çok Doğu Asya kökenli oldukları da ortaya çıkmaktadır. Bu açıdan teknooryantalizmin 1980'lerde yükselişi ABD tarafından Asya-Pasifik ülkelerinden algılanan tehlikeyi de yansıtmaktadır (Sohn, 2008, s. 8). Benzer şekilde 1980'li yıllar Japon karşıtı (Japanophobic) fikrin yükselişe geçtiği bir dönemdir ve bu durum tekno-oryantalizm ile yakından bağlantılıdır (Rivera, 2014, s. 70). Yine aynı yıllarda, "Asya Kaplanları" olarak adlandırılan Doğu Asya ülkeleri, Batı liderliğindeki teknolojilerin kopyalayıcıları/ sağlayıcıları olmaktan yeni teknolojilerin mucitleri/ girişimcileri olma yolunda hızlı hareket etmeleri dikkat çeker (Cornea, 2007, s. 194). Asya şirketleri teknoloji temelli para kazanması sonucu özellikle Batı'da köklü şirketleri satın alır. Sony'nin 1989'da Columbia Pictures'ı, 2005'te MGM'yi devralması dikkat çeker (Cornea, 2007, s. 194-195). Sony gibi Doğu Asya şirketlerinin başarılarının yükselmesi karşısında Hollywood şirketlerine ABD hükümeti yeni yasalar ile destek vermeye çalıșır (Dickenson, 2006, s. 48). Temelde bu yasalar Doğu Asya şirketlerinin Amerika'da faaliyetlerini kısıtlamaya yöneliktir.

Klasik oryantalizm genel hatları ile Avrupa ile Ortadoğu arasındaki bir ilişsiler pratiğini resmetmeye çalışırken tekno-oryantalizm kabaca Amerika Birleşik Devletleri ile Doğu Asya ülkeleri (başta Japonya ve Güney Kore, günümüzde ise Çin) arasındaki güç mücadelesini ifade etmeye çalışmaktadır. Tekno-oryantalizm temelde ABD'de gözlemlenebilir olan Japonya ve Doğu Asya ile ilgili kültürel paranoya dalgasıdır (Morley ve Robins, 1995, s. 6). Bu bağlamda Said'in oryantalizmindeki Avrupa ve Orta Doğu zıtlığının yönü değişir. Günümüzde Japonya, teknolojik yenilikte ABD ile rekabet ederken, Çin ise emek ve üretimde ABD ile rekabet içindedir; Japonya teknoloji yaratır, yenilik yapar; Çin ise teknolojiyi üretir (Roh, Huang ve Niu, 2015, s. 4). Aynı șekilde Çin defalarca dünyanın bir sonraki süper gücü olarak sunulduğunda, Batı ülkelerindeki izleyiciler tarafından tehdit olarak algılanır (Lozano-Méndez, 2010, s. 190). Klasik oryantalizmde Doğu'nun Batı'ya göre teknolojik ve ekonomik olarak düşük seviyede olduğu söylenirken tekno-oryantalizmde ise Doğu Asya teknolojik/ekonomik olarak yüksek seviyededir. Klasik oryantalist söylemde Biz (Batı) "uygar" ve onlar (Doğu) "barbar" çatışması varken tekno-oryantalizmde Biz (Batı) "insan" ve onlar (Doğu) "robot" zıtlığı vardır (Morley ve Robins, 1995, s. 170). Ueno’ ya göre ise tekno-oryantalizm bağlamında iki çatışma alanı vardır. Birincisi, insan ile makine, insan ve ağ arasındaki zıtlık; diğeri Japonya ve ötekiler (Batı) arasındaki ilişki temelinde zıtlıktır (Ueno, 2002, s. 229). Burada vurgu teknolojik olarak gelişmiş ama insanlıktan çıkmış Doğu Asya imgesidir. Tekno-oryantalist söylemde ruhsuz Asyalıların karşısında hümanist ve özgür ruha sahip Batılı karşıtlığı bulunur (Choe ve Kim, 2015, s. 114). Aynı şekilde tekno-oryantalizmde Asyalılar kendilerini üstün teknolojik/verimlilik ve kapitalist uzmanlık ile idare etseler bile, duygusal yokluk içinde daha da kötüsü, insanlık dişı hümanizm içinde resmedilirler (Sohn, 2008, s. 8). $\mathrm{Bu}$ bağlamda robotlar ve video oyunları gibi fütüristtik resimlere vurgu yapmak Japon halkının duygulardan yoksun görünmesini sağlamaktadır (Nihei, 2009, s. 89).

Klasik oryantalizmde Doğu sabit değişmez ve Batı'dan alçakta tarif edilmektedir. Teknooryantalizm ise Doğu Asya halklarını Batılılarınkinden "farklı" bir zamansız ve değişmez kültürü yaşadığı şeklinde tasvir etmez (McKay, 2017, s. 944). Bunun temel nedeni ekonomik, kültürel ve özellikle teknolojik olarak Doğu Asya'nın geliștiğini Batı'nın da 
kabul etmesidir. Aynı şekilde tekno-oryantalizm hayali, Doğu Asya toplumlarını Batı ile aynı gelişimsel yörüngeyi izlediğini varsayar (McKay, 2017, s. 944). Böylece Doğu Asya'nın modernleşmesinin Batı kaynaklı olduğu vurgulanır. Ancak burada farklı bir vurgu da yapılmaktadır. Batı teknolojiyi demokrasi, insan hakları ve özgürlük gibi olumlu yönde kullanırken Doğu Asya ise kişisel zevk ve çıkarları için kullanmaktadır.

Tekno-oryantalizmde, Japonya sadece coğrafi olarak değil, aynı zamanda kronolojik olarak da projelendirilir. Japonya sürekli yakın gelecek ile ilişkilendirilmektedir (Ueno, 1999, s. 98). Batı'nın kurguladığı bu hayali gelecek ise Japonya'nın önüne geçmek isteyen ya da Japonya'yı gelecekte aşağıya çekmek isteyen Batı'yı da ifade eder. Bu bağlamda klasik oryantalizmde Doğu'nun özellikle geçmişi kötü olarak sunulurken; tekno-oryantalizmde Doğu Asya ülkelerinin gelecekleri olumsuz olarak tasvir edilir. Tekno-oryantalist söylem, Japonya'yı kapitalizmin distopik geleceği olarak sunar (Wagenaar, 2016, s. 49). Bu distopya dijitalleșme temelinde teknolojik yabancılașmanın merkezi olarak Japonya'yı betimler (Goto-Jones, 2015, s. 34). Ayrıca bu bakış açısından Japonya'nın teknolojik olarak ilerlemesi Batı geleceğini kültürel olarak olumsuz etkileyecektir. Oryantalizm, Batı'nın kimliğini olușturma işlevini yerine getirmiștir; tekno-oryantalizm, Batı kimliğini gelecekteki olumsuzluklardan korumak için kurulmuştur (Ueno, 1999, s. 95) . Diğer bir ifade ile ekonomik, kültürel ve teknolojik olarak düşüşe geçen Batı'yı gelecekteki konumu için olumlamaya çalışmakta Japonya ve diğer Asya ülkelerini olumsuzlamaktadır. Öte yandan Asya kültürlerinin dünyanın geleceğini ele geçirmesini engellemeye çalışmak temel amaçtır. Buna Batının tekno-oryantalist düşünceler ile Japonya'ya egemen olma girişimleri de denilebilir (Wagenaar, 2016, s. 50). Tekno-oryantalizm sömürgeci söylem türüyle yani sömürgeci bakışla da ilgilidir (Marchart, 1998, s. 59). Diğer bir ifade ile klasik oryantalizmdeki sömürgeci tutum, tekno-oryantalizmde de kısmen görünmektedir. Klasik oryantalizmde hegemonik bir Batı'nın Doğu'daki temsili otoritesinin öngörülmesi, teknooryantalizmde ticaret ve sermaye akışının karşılıklı oluşturduğu geniş ve iki yönlü etki vardır (Roh, Huang ve Niu, 2015, s. 3). Bu bağlamda tekno-oryantalizmde Batı ülkelerinin Doğu Asya ülkeleri üzerinde tahakküm edici bir etkisinden söz edilemez. Tersine teknoloji bağımlısı Asya'nın tüm dünyayı ve tabii ki Batı'yı olumsuz etkileyeceği vurgulanır. Diğer yandan bunu engellemek için Asya ülkeleri kötü olarak gösterilmeli ya da sunulmalıdır. Bu suretle Batı'nın kültürel, teknolojik ve ekonomik olarak Asya'dan etkilenmemesi ve kendi köklerine dönmesi amaçlanır.

Tekno-Oryantalizm, 11 Eylül saldırıları ve 2008 Mortgate krizi göz önüne alındığında, terörizm ve ABD'nin ekonomik kırılganlığı konusundaki endişelere de aracılık eder (Tzarina ve Fung, 2015, s. 207). Siyasi ve ekonomik olarak zor durumda kalan ülke ya da ülkeler hayali bir düşman, problem tanımlayarak vatandaşlarının birlikte hareket etmesini, kenetlenmesini sağlamaya çalışır. Tekno-oryantalizm Amerikan egemenliğinin büyümekte olan bir Doğu Asya ekonomisi tarafından zayıflatıldığı iddiasını da taşır (Cornea, 2007, s. 195). ABD özellikle 2000'li yıllar içinde yaşadı̆̆ siyasi ve ekonomik sorunları Doğu Asya ülkelerini ötekileştirerek bertaraf etme amacındadır. Bu açıdan oryantalist unsurlar her zaman iktidar ve güç ilişkisini akla getirmektedir.

\section{Hollywood ve Tekno-Oryantalizm İlişkisi}

Genel olarak Amerikan düşüncesi, tarihsel süreçte politik sahada kötü olduğu ülkeleri ya da toplumları kitle iletişim araçları özellikle filmler ve son yıllarda diziler yoluyla olumsuz olarak resmetmektedir. 
Filmler, herhangi bir durumu yansıtmaktan çok, o durumun tasarlanan belli bir biçimini oluşturmak üzere seçilmiş ve birleştirilmiş temsili öğeler yoluyla birtakım tezler ileri sürer, bunu yaparken, seyirciye belli bir konumu ya da bakış açısını telkin ederler. Hollywood sinemasında olup bitenlerin çoğu, yukarıda özetlediğimiz anlamda gerçekten de ideolojiktir. (Ryan ve Kellner, 2010, s. 18).

$\mathrm{Bu}$ açıdan filmler ideolojik yeniden üretim aracı olarak görülebilir (Özden, 2004, s. 166). Buradaki ideoloji dönem içindeki egemen düşüncenin üretimine dayalıdır. Diğer bir ifade ile sinema egemen ideolojinin değerlerini benimsetmeye çalışabilir (Yılmaz, 2008, s. 66). Hollywood filmleri içinse genel olarak Amerikalı, Beyaz, Anglo-Sakson, Protestan- (WASP) değerler ön planda tutulmaktadır. Egemen ideolojinin en önemli özelliklerinden biri, içinde bulunulan durumu (kültürel, ekonomik, politik vb.) doğal, gerçek ve değiştirilemez olarak göstermektir (Yılmaz, 2008, s. 71). Bunu yaparken sinema çeşitli hikayeleştirme biçimlerine başvurur. Genel olarak sinema, farklı görme biçimleri sunan temsiller bütünüdür; insanın olayları ve nesneleri daha önce hiç görmediği veya deneyimlemediği biçimlerde algılatmaya çalışır (Kellner, 2013, s. 29). Bu bağlamda sinemanın manipülatif etkisi ortaya çıkmaktadır. Seyirciye kavram, olgu, durum ya da kişileri belirli çerçeveler ile sunar. Diğer bir ifade ile Hollywood Amerika'nın ideolojisinin yayılımını veya meşrulaştırılmasını sağlayan bir araç işlevi görür. Böylece Amerika'nın kendi hegemonyasını diğer ülkeler üzerinde oluşturmasına aracılık eder. Örnek vermek gerekirse Japon yapımı ilk Godzilla (1954) filmi Amerika'nın İkinci Dünya Savaşı'ndaki nükleer bombaları dolayısıyla oluşan bir canavarı simgelemektedir. Bu bağlamda eleştirel bir tavrı da vardır. Ama daha sonraları Hollywood yapımı yeniden çevrimlerde Godzilla canavarından, Amerikan ordusu sayesinde kurtulan dünya imajı bulunmaktadır. $\mathrm{Bu}$ açıdan uzun zamandır Amerikan sinema sektörü olayları kendi Batılı zihnine uygun hale getirmektedir.

1980'li ylllar ise ekonomik olarak teknoloji üretiminin iyice Doğu Asya ülkelerinin hâkimiyetine girdiği bir dönemi ifade eder. Bu bağlamda 1980'li yıllardaki filmlerde sevimli ve komik, tehdit edici ve küçük düşürücü Asya imgeleri tarafından yönetilen ABD'deki mali, bölgesel, kültürel ve teknolojik alanlardaki "Asya istilasının" korkularına tanık olunur (Nguyen ve Tu, 2007, s. 2). Genel yaklaşım sinema sanatında özellikle 1980'li yıllarda bilim kurgu/cyberpunk filmler ile tekno-oryantalizmin başladığı yönündedir. Kosnik ise buna karşı çıkarak tekno-oryantalist söylemin Hollywood'da köklerini daha eski tarihlerde bulur (2015, s. 90). Ona göre tekno-oryantalizm Fu Mançu'nun Maskesi (1932) filmi ile başlar. Fu Mançu'nun Maskesi, Amerika Birleşik Devletleri'nde yirminci yüzyılın başlarında yaygın olan "sarı tehlike" yani Asyalı göçmen karşıtı duygularını ve Japon emperyalizminin yükselişiyle ilgili Amerikan rahatsızlıklarını vurgulamaktadır (Kosnik, 2015, s. 90). Bu filmi tekno-oryantalist söylem içinde değerlendirilmesini sebep olan ise Fu Manchu'nun bilimsel deneyler ve elektronik icatlar yapması ve bunları insanlığa karşı kullanılmasıdır.

Gelecekte ileri teknolojik bir ortamda Asyalıların ötekileştirilmesi en bariz olarak öne çıkaran film ise 1982 yapımı Blade Runner'dır. Filmde yapay insanın ölümü ve anlatısal bağlamda teknolojik olarak üretilmiş tehdit edici yapay bedenin ortadan yok olması temelinde insanın ve insanlığın da zaferi vurgulanır (Tzarina ve Fung, 2015, s. 196). Dikkat edilirse insanlığa dair tehlikenin Asyalılardan geleceği düşüncesi bağlamında tekno-oryantalizm fikrinin filmsel olarak öne çıktığı görülmektedir. Blade Runner'da, Los Angeles'da ırksal ve sosyo-ekonomik alışkanlıklar farklılık gösterir; sokak seviyesindeki ticaret, neredeyse tamamen Asya yapımı mal satan Asyalılar tarafından özellikle temel teknolojilerde alım-satım yaparak gerçekleştirilmektedir. Bu manzarada, beyaz adam 
olarak Deckard marjinalleştirilir, ekonomiye tam olarak katılamaz; suşi barında bir yer için sabırsızlıkla bekler ama sonra istediği yiyecek miktarını alamaz (Yu, 2008, s. 57). Bu bağlamda Amerika gelecekte Asyalıların istilasına uğramış olarak tasvir edilmektedir. Amerika'nın esas sahibi görülen beyaz adam da dışlanmış ve alt seviyeye düşmüştür ya da düşürülmüştür. Blade Runner filminde robotların sahip olduğu duygu, temelde yeni teknolojinin ürünüdür ve bu makine-insanlar, birçok bakımdan, insandan daha fazla insani nitelik gösterirler (Ryan ve Kellner, 2010, s. 387). Tekno-oryantalist söylemde teknoloji insanların yararına değil özellikle insanların zevk ve şehvetine yönelik kullanıldığı vurgulanmaktadır. Bunun en iyi örneklerin de biri de Blade Runner filmidir, insanlar robotlar yardımı ile duygusal ve cinsel ilişkiler geliştirmektedir.

Kosnik, Sinbad'ın Oğlu (1955), Yıldız Savaşları IV: Yeni Bir Umut (1977), Mortal Kombat (1995), Isyan (2002), Matrix film üçlemesi (1999-2003), Indiana Jones filmleri (19812008) gibi Hollywood ticari sinemasinda az ya da çok tekno-oryantalist unsurlara rastlanıldığını belirtmektedir (2015). Ueno (2002) ise Ghost in the Shell (1995) filminde tekno-oryantalizm söyleminin var olduğunu belirtmektedir. Suzuki, Battleship (2012), Pacific Rim (2013) ve Godzilla (2014) filmlerinde Amerika'nın, Asya-Pasifik ülkeleri temelinde birleştirici güç olacağı mesajı verildiğini ve tekno-oryantalizmin daha yumuşak biçimde kullanıldığını belirtir (Suzuki, 2017). Tekno-oryantalizm bağlamında olmasa da Batman Başlıyor (2005) filminde Ninjaların Amerika'ya kötülük getirdiği vurgulanmaktadır (Park, 2010). Bu açıdan Hollywood filmlerinin tekno-oryantalist söyleminin seyirciye iletilmesinde ve yayılmasında kullanıldığı görülmektedir. Amerika Birleşik Devletleri sinemada hâkimiyet sürdürdükçe, hem ekonomik hem de askeri sebepler nedeniyle, Hollywood filmleri Asya ve Asyalılar için tekno-oryantalist söylemleri kullanmaya devam edecektir (Kosnik, 2015, s. 100).

\section{Araştırmanın Metodolojisi}

Oryantalizmde ya da tekno-oryantalizmde hayali bir düzenin ya da öteki algısının oluşturulması amaçlanır. Temel olarak istenilen insan düşüncesinin yönlendirilmesidir. X-Men serisi filmler içerisinde değerlendirilebilecek Wolverine gibi ana akım Hollywood filmleri daha çok izleyici çeken yapımlardır. Bu açıdan seyircinin sinemaya gitmesi en azında filmin söylemi bağlamında egemen düşünceden etkilenme olasılığını yükseltir. Türkiye'de The Wolverine filmi yaklaşık 500 bin kişi tarafından izlenmiştir (https:// boxofficeturkiye.com/, 2013). Aynı şekilde Türkiye'de 2013 yılında en fazla izlenen 22. filmdir; yabancı filmler arasında ise en çok izlenen 9. filmdir. (https://boxofficeturkiye. com/, 2013). The Wolverine bütün dünyada 2013 yılında en fazla izlenen 15. filmdir (https://www.boxofficemojo.com/, 2014). Bu bağlamda filmin geniş kitlelere ulaşması anlatıdaki egemen düşüncenin etki alanını da arttırmaktadır.

Çalışmanın amacı Türkçe yazında sosyal bilimler alanında çok incelenmemiş olan teknooryantalizm kavramı bağlamında The Wolverine (2013) filmini çözümlemektir. Teknooryantalizm kavramı özellikle bilimkurgu ve cyberpunk filmlerde sıklıkla karşılaşılır. $\mathrm{Bu}$ bağlamda çalışmanın evreni özellikle teknoloji temelli Hollywood bilimkurgu filmleridir. The Wolverine filminin örneklem olarak seçilmesinin nedeni sinema seyircisi tarafından X-Men serisinden tanınan, bilinen ve ölümsüz bir karakterin Amerika Birleşik Devletleri’nin gücü bağlamında ideolojik temsil için uygun olmasıdır.

Süpermen 1 ve 2 (1978 ve 1980), 1970’lerin sonlarındaki ve 1980’li yılların diğer süper kahraman filmleri, Amerikan halkının bir tahayyülünü, ülkeyi 1960’lar ile 1970'lerden gelen belirsizlik bataklığından kurtarıp Reagancı bir muhafazakârlığı besleyerek eski Amerika'yı 
yeniden tesis edecek bir Kurtarıcı'ya, insanların günahlarının kefaretini ödeyecek birine olan özlemi gösterir (Kellner, 2013, s. 24).

Hollywood süper kahraman filmleri özellikle Amerika'nın siyasal, ekonomik ve kültürel olarak görece güçsüz olduğu hissini gidermek için kullanılabilmektedir. Ek olarak çalışmada sinemanın ideolojik bir aygıt olduğu temelinden yola çıkarak filmin içinde seyirciye empoze edilen tekno-oryantalist fikirler ortaya çıkarılacaktır. Araştırmada betimsel film analizi yöntemi kullanılmıştır. Bu açıdan kuramsal kısımda açıklanan tekno-oryantalizm özelliklerinin filmin anlatısında kullanılıp kullanılmadığı ve ne sıklıkla kullanıldığı ortaya konmaya çalışılacaktır.

\section{Filmin Özeti}

Wolverine, 2. Dünya Savaşı'nda hayatını kurtarmış olduğu Yashida'nın yardım isteğiyle Japonya>ya gider. Yashida yaşlanmıştır; Japonya'da birçok şirketin sahibi zengin biridir. Wolverine, artık ölümsüz olmak istememektedir. Yashida, Wolverine'nin ölümsüzlük gücünü alıp kendi kullanma amacındadır. Yashida'nın torunu Mariko'yu, babası miras için öldürmeye çalışır. Wolverine, Yashida ve ona bağlı Yakuzalar ile savaşır. Wolverine hem kendini hem de Mariko'yu koruma amacındadır. Bu ikiliye geleceği görme yetisi olan Yuriko yardım eder. Yashida adamantiyumdan dev bir samuray inșa eder ve dev robotun içinde oturarak kendisi kontrol eder. Wolverine ve Mariko birlikte savaşarak Yashida'nın dev Samuray robotunu yok ederler.

\section{Wolverine Filminin Tekno-Oryantalizm Temelinde İncelenmesi}

Filmin anlatısı, ABD'de tarafından Japonya'ya atom bombasının atılması ile başlar. Japonya temelinde Doğu Asya toplumlarının teknolojik ilerlemesi 2. Dünya savaşından sonra değişim gösterir. 2. Dünya Savaşı, özellikle Hiroşima ve Nagazaki'nin atom bombalarıyla imhası ve binlerce ölüm, Japonların teknolojileriyle olan ilişkisini derinden değiştirir (Yamashita ve Pablo, 2017, s. 175). Diğer yandan atom bombası, Japonya'nın öz kimliği için yeni bir çağ başlatır ekonomik bir ortak taahhüt fikrine bağlı, bilim ve teknoloji ile beslenen büyüme, Japon halkının geleceğe bakmaya devam etmelerini sağlayan bir tür tekno-milliyetçilik sağlar (Low, 2003, s. 197-198). Bu bakımdan teknolojik gelişmenin Japonya'da temel değer haline gelmesi ile filmin anlatısının başlangıcı aynıdır. Filmde nükleer bomba atıldıktan sonra ülkesinin halini gören Yashida şok geçirir; bu durum binlerce Japon için de geçerlidir.

Filmde Yashida, Wolverine'i kurtarmak ister Wolverine'in cevabı ise : “Gelen şeyden kaçamazsın" olur. Wolverine'in gelen dediği şey atom bombası özelinde kaçlamayacak olan Amerikan hâkimiyeti ve otoritesidir. Yashida'nın komutanları, harakiri yapıp kendini öldürmesini ister ama o kendini öldürecek onurlu ve geleneksel Japon davranışını sergileyemez. Daha sonra Wolverine: "Burada daha güvenli olursun" sözleri ile aslında Japonya'nın ABD’nin yanında koruması altında olması gerektiği vurgulanır. Nükleer felaketten kendini siper ederek Yashida'yı korur. Wolverine'nin her ne kadar zor şartlarda olursa olsun kendini yenileme ve yeniden güçlenme gücü bulunmaktadır. Filmin tamamında Amerika Birleșik Devletleri ile Wolverine'in birbirine eş değer kabul edildiği görülmektedir. Diğer bir anlatımla filmde Wolverine Amerika'yı simgelemektedir. Bu açıdan Amerika sonsuz bir iyileşme gücü ve yeniden güçlenme ile bir tutulur.

Filmin başlangıcı Wolverine'nin hayattan koptuğu insanlardan uzakta yaşadığı bir dönemdir. İnsanların hayatlarına müdahale etmediği ve geri planda olduğu bir zaman dilimidir. Öte yandan Wolverine'nin bu tavrı dünyanın gidişatı için iyi olarak sunulmaz. Dünya yaşamının düzelmesi ve dengelenmesi için Wolverine'nin kendine gelmesi ve 
müdahalede bulunması gerekmektedir. Filmin anlatısında Wolverine ve bu temelde Amerika'nın, Dünya Savaşı'ndan sonra teknolojik olarak gelişmekte olan Japonya'yı engellemesi gerektiği zımnen vurgulanmaktadır.

Wolverine doğaya saygıyı, insanlara yardımı temsil etmektedir. Bu bağlamda yaşadığı Amerika dağlarında çeşitli yaban hayvanları ile dost biçimde temsil edilmektedir. Örnek olarak avcılık yapan bir grubun zehirli oklarla öldürdüğü ayı için Wolverine intikam alır. Burada filmin ana temalarından biri de göze çarpar. İnsanın doğadaki yaşamı ve ileri teknoloji hayat arasındaki fark seyirciye betimlenir. Filmsel evrende Amerika'nın doğal hayatı temsili ve kötü rakiplerinin ileri teknolojiyle imlenmesi Rocky 4 (1985) filminde de başvurulan bir yöntemdir. 0 günün şartlarında Amerika'nın düşmanı olarak görülen Sovyetler Birliği'ni temsilen boksör Ivan Drago son teknoloji araçlar ve makineler ile antrenman yaparken Amerika Birleşik Devletleri'ni temsil eden Rocky dağda kütük çekerek ve karda koşarak hazırlanır. Bu açıdan olumsuz imaja sahip ülke değişirken Hollywood'un sunum biçimleri çok değişmemektedir.

İkinci Dünya Savaşı'ndaki Pearl Harbor saldırısı tekno-oryantalistlerin korkutucu imgeleri için temel kaynaklardan biridir (Hough, 2015, s. 39). Japonların özellikle kendilerini feda etmeye yönelik yaptıkları saldırılar ve Amerikan ordusuna büyük kayıp verdirmeleri Batı'nın bilinçaltında Japonya'nın bir korku figürü olarak düşünülmesini sağlar. Ancak film bir başarısızlık simgesi olan Pearl Harbor'ı hiç vurgulamaz tarihi gerçekler ile kurgusal (fiction) olayları iç içe geçirerek seyircinin algısını yönetmeye çalışır. Bu bağlamda filmin anlatısında bir tarihsizleştirme çabası da dikkat çekmektedir. Wolverine'nin neden Japonya'da tutsak olduğu ve neden Japonya'nın bombalandığl şehirlerde bulunduğu anlatıda üzerinde durulmadan es geçilir. Filmde Nagazaki yani atom bombasının atıldığı yer ise klasik oryantalist Batı düşüncesinin merkezini simgelemektedir. Wolverine ve Mariko, kötü Japonlardan sığınmak için geleneksel bir Japon evine giderler. Komşular ile iyi ilişkiler içindedirler, satıcı onlara elma verir,Wolverine halka yardım eder. Filmin vurguladığı düşünce Amerika ve Japonya'nın mutlu olarak yaşayacağı yerin klasik Batı oryantalist bakışın evreni olduğudur. Diğer bir ifade ile Amerika'nın üsünlüğünü kabul eden Japonya mutlu ve güvendedir. Filmsel anlatı klasik oryantalizm içinde nostaljik Japonya'yı övmekte ve ona kişilerin öykünmesini sağlamaktadır. Teknolojik Japonya ise film temelinde olumsuzlanmaktadır.

Batılı klasik oryantalist bakış açısı Japonya'yı iki ana noktada betimlemektedir. Bu açıdan Japonya'nın feminen kalitesi ve zarafeti vurgulanır veya toplumsal olarak şiddetli doğası öne çıkartılır (Nihei, 2009, s. 87). Diğer bir ifade ile Japonya uzun zamandan beri Batı tarafından geyșa ve samuraylarla dolu geleneksel bir toplum olarak algılanmaktadır (Wagenaar, 2016, s. 47). Aynı şekilde Japonya temelinde geyşa cinselliği, samuray ise şiddeti betimlemektedir. Wolverine, filmin hemen başında geleneksel bir Japon evinde geyşa ve samuraylar ile tanışır. $\mathrm{Bu}$ açıdan film anlatısının girişinde Batı'nın zihinsel evrenindeki klasik Japonya imgesi yer almaktadır. Örnek olarak küçük bonsai ağaçlar, yerel terlikler, Japon mimarisinde bir minka ev, geleneksel kimonolarıyla hizmetçiler ve yan odada dövüșen samuraylar ile Batı'nın istediği otantik Japonya betimlenir. Hatta kimono giyen yaşlı Japon kadınlar Wolverine'in hizmetinde görevlendirilir. Film temelinde Mariko Japon kadınlığını, güzelliğini, inceliğini vurgulayan klasik oryantalizmin egemen bakışı altındadır aynı şekilde Samuraylar ve Yakuzalar sürekli kavga eden, bıçak çeken, silah ateşleyen insanlar olarak Batının görmek istediği Japonya'nın şiddetli kısmını ortaya koyar. Bu açıdan filmde Japonya Batılı göz ile güzel geyşalar ve kavgacı samuraylara indirgenir. Japonya'nın teknolojik olarak ileri olmasının herhangi 
bir olumlu durumu gösterilmez. Hatta tersine Japonya teknolojik olarak geliştiği için kötüdür imajı oluşturulur.

Japonya, Batı için geleneksel bağlamda Zen, kabuki, geyşa, samuray ve kamikaze gibi "egzotik" ve "gizemli" bir alandır (Morley ve Robins, 1995, s. 6). Bu otantik bilinmezlik özellikle Wolverine karakteri temelinde Batılı erkeğin gözü ile aktarılmaktadır. Film Mariko'nun fiziksel ve zihinsel olarak sahip olunması bağlamında Wolverine'nin normale dönmesi ile sonuçlanır. Diğer bir ifade ile Mariko'ya sahip olmak Japonya'nın, Amerika'nın istediği şekilde evrilmesi anlamına gelir. Böylece Japonya teknolojik gelişmenin kötülügünden kurtulduğu gibi Wolverine de ruhsal sağlığını stabil hale getirir. Aynı şekilde Batı bütün dünyayı kurtaran kahramanlığına devam eder. Filmde Japon kızı Mariko yetenekli bir lider ya da iş kadını olarak gösterilmez bunun yerine, yalnızca Amerikalılar tarafından kurtarılan güzel bir kız olarak sunulur (Wagenaar, 2016, s. 49). $\mathrm{Bu}$ durum klasik oryantalizmin fethedilecek, korunacak ya da kurtarılacak güzel kadın imgesinin bir yansıması olarak düşünülebilir. Mariko hayatındaki çeşitli erkeklerin piyonu olur ve nihayetinde kurtarılması gerekir; elbette Wolverine tarafından ve bu durum Amerikalıların zihinsel dünyalarında rahatlamasına yardım eder (Napier, 2013). Mariko hem modern, hem güzel hem duygusal Japon kadın imgesini temsil etmektedir. Ek olarak Japonya'nın klasik oryantalizm bağlamında egzotik özelliklerini de yansıtmaktadır. Tekno-oryantalist ortamda Mariko'yu son anda intihar ederken kurtaran Wolverine'dir. $\mathrm{Bu}$ durum iki bakımdan önemlidir, birincisi Batılı kahramanın kadını kurtarması (ki Japon erkeklerin neredeyse tamamı film boyunca kötü olarak tanımlanmaktadır) ikincisi Japonya'nın yükselişinin, klasik oryantalizmi öldürmesinin Batı kaynaklı olarak engellenebileceğinin vurgulanmasıdır.

Japonya filmin başında 2. Dünya savaşını kaybettiği için geleneklerine göre onurlarını kurtarma çabasındaki askerler ile resmedilir. Filmin günümüzde geçen kısmında ise tam tersi bir tanımlama yapılır. Japonya Adalet Bakanı mafya ile ilişkiler içinde betimlenir, Japonya'da nüfuz sahibi kimseler kendi çıkarları için polisi yönetmektedirler, polis amirlerinin hepsi halkı değil büyük teknoloji şirketinin patronunu dinlemekte ve onun çıkarını korumaktadır. Film güçsüz, bombalama karşısında hiçbir şey yapamayan Japonya'yı istemektedir. Bu bağlamda tekno-oryantalizmin hâkimiyetindeki Japonya suça ve adaletsizliğe yatkın olarak betimlenmektedir.

Film Wolverine'ni ABD temelinde Batı'nın bir temsili olarak sunar. Aynı şekilde Yashida da Japonya'nın simgesi olarak durmaktadır. Wolverine ile yıllar sonra ilk karşılaşmalarında Yashida'nın: "O zaman da ölmeye hazır değildim şimdi de ölmeye hazır değilim ama sen hazırsın" sözleri İkinci Dünya Savaşı'ndan beri yok edilmeye çalışılan Japonya ve bunun karşısında günümüzde yok olmaya giden Amerika Birleşik Devletleri imgesi oluşturmaktadır. Wolverine'nin film boyunca güçsüzleștirilmesi ve sürekli olarak öldürülmeye çalıșılması Batı'nın gelecekte kültürel, ekonomik ve siyasi olarak tükeneceğinin de paranoyasıdır. Filmde tekno-oryantalizm temelinde bir yandan Japonya'nın teknolojik, ekonomik ve güç üstünlüğü vurgulanırken diğer yandan Japonya’yı gelecekte Amerika Birleşik Devletleri temelinde bütün Batı medeniyeti için bir tehdit olarak göstermek amaçlanmaktadır. Birçok Batılı, Japonya'yı, soğukkanlı çalışanlar tarafından hesaplanan, matematiksel verimlilik ve teknoloji ile takıntılı bir ülke olarak görmektedir (McLoad, 2013, s. 260). Filmde ise teknoloji ve insan karşıtlığının birçok kez vurgulandığı görülmektedir. Japonya $500 \mathrm{~km}$ hızla giden dünyanın en hızlı trenine sahiptir ama trendekiler masum bir kadının öldürülmesi konusunda umursamazca davranmaktadır. Büyük salonlarda elektronik oyun makinelerine bağımlı onlarca insan 
betimlenir; bu kişiler Wolverine ve Yakuzalar arasındaki kavgada ölenleri görmezler ve umursamazlar. Japonlar teknolojik gelişme temelinde cyborglar veya insan kopyaları olarak değerlendirilir. Bu, Japonları insanlık dıșı olarak imgelemektir (Morley ve Robins, 1995, s. 170). Batı'nın politik ve kültürel bilinç dışılığı içinde Japonya, boş ve insanlık dışı teknolojik güç figürü olarak ortaya çıkar. Kapitalist ilerlemenin yabancılaşmış ve distopik imajını temsil ederler; bu hem kızgınlığı hem de kıskançlığı beraberinde getirir (Morley ve Robins, 1995, s. 170). Film bu bağlamda bir ters-düz etme işlevine girişir. Temel olarak mutant olan Wolverine'dir. Öte yandan Wolverine de temel olarak insan olmasa da filmin anlatısı içinde güçleri baskılanır ve filmin büyük bir bölümünde normal insan gibi hareket eder. Diğer bir anlatımla Wolverine insanlaştırılır buna karşın Yashida adamantiyumdan yapılmış devasa bir Samuray robotun içinde Wolverine'in gücünü emen ruh sağlığı bozuk bir yarı-insan portresindedir. Japonya'daki insanlar Yashida temelinde ölümsüzlük peşinde koşan yarı robot-yarı insan, cyborglar şeklinde tasvir edilir. Ek olarak tekno-oryantalizm irksal bir sorunu da ifade ederek beyaz üstünlükçü kültürü de ortaya çıkarır (Ishii, 2015, s. 183). Bu bağlamda filmde Japonya/Doğu Asya ve Batı arasında dengeli bir betimleme bulunmamaktadır. Batı tekno-oryantalist söylem yoluyla ahlaki ve kültürel üstünlüğü ele geçirmeye çalışmaktadır (Wagenaar, 2016, s. 49). Japonya özellikle gelenekselliği ile öne çıkmış dürüstlük, onur, ahlaka önem veren yapısı ile Batı'da tanınmıștır. Samuraylar zedelenen onurlarını kurtarmak için harakiri yaparak kendilerini öldürmüşlerdir. Batı, Japonya temelinde Doğu Asya'nın teknolojik üstünlügünü kabul etmiş ama buna karşın bu üstünlüğün ahlaki olarak Doğu'yu çökerttiğini ima etmiștir.

Digital çağda Batılı zihin için, teknoloji temelli Doğu Asya ekonomileri ve teknolojiye düșkün Doğu Asyalılar bir endișe kaynağı olarak durmaktadır (Yeats, 2015, s. 126). Wolverine Japonya'ya ayak bastığında ona eșlik eden Japon kadın büyük bir ekonomiye ve güçlü teknolojik ürünlere sahip olduklarını açıkça anlatır. Bunu sağlayan kişi olarak da Tanrısal bir güç olarak gördükleri Yashida'yı işaret eder. Bu bağlamda Yashida Japonya temelinde Doğu Asya toplumlarını ileriye götüren teknolojik yeniliklerin tümünü de temsil etmektedir. Mariko'nun ifadesi ile Yashida'nın bir gözü geçmişe bakarken bir gözü geleceği görür. Filmde klasik ejderha işlemeleri olan kapıdan geçerler, kapının içerisi teknolojik tıbbi aletler ile donanmış ve Yashida'nın yaşaması için tesis edilmiştir. Yashida son teknoloji bir yatakta yatmaktadır; yatak bütün vücut hareketlerine göre şekil değiștirmektedir. Yashida'nın Japonya'yı temsil ettiği düşünüldüğünde temel olarak Doğu Asya ülkelerinin teknolojik gelişme sebebiyle yaşamlarını devam ettirdiği vurgusu yapılmaktadır. Ancak Yashida hayatını devam ettirebilmesi için Wolverine'in kanına mutlak ihtiyaç duyar. Yashida hastalanmıştır o hastalanınca Japonya'nın karanlık günleri de başlamıştır. Japonya temelinde Yashida'nın yeniden iyileşmesi için gerekli olan ise Wolverine'in kanıdır. Filmde bu durum aslında Japonya'nın, Amerika'ya muhtaçlık ilişkisini de ortaya koymaktadır. Japonya teknolojik olarak ne kadar ilerlese, zenginleșse ve refah seviyesi yükselse de ABD'ye ve onun desteğine ihtiyaç duyar. Diğer bir ifade ile Doğu Asya ülkeleri teknolojik, ekonomik vb. ne kadar gelişmiş olurlarsa olsunlar Amerika'ya muhtaçtır fikri seyirciye iletilmeye çalışılmaktadır.

Filmde Batı'nın Wolverine temelinde güç, kültür, doğruluk, ahlak, cinsellik vb. alanlarda üstünlüğü vurgulanmaktadır. Aynı şekilde tekno-oryantalizm Doğu Asya'ya Batı merkezli bir hegemonyayı yerleştirme biçimidir (Sohn, 2008, s. 9). Film özelinde değerlendirildiğinde kurtarıcı olarak doğruyu yapan ve söyleyen Batılı bir kahramandır. Anlatıda iyi olarak temsil edilen bütün Japonlar da Batılı kahraman Wolverine destek olan kimselerdir. Japonya temelinde Doğu Asya'ya adaleti getirecek düzeni sağlayacak 
kişi de Wolverine'dir. Filmin sonunda görevini tamamladıktan sonra Wolverine huzurlu bir şekilde ülkesine geri döner. Japon kız Yuriko gelecekte neler olacağına bilendir, diğer bir anlatımla gelecek bilgisi onu herkesin ve her şeyin üstünde konumlandırır. Beraber seyahat ederlerken Wolverine: "Bu uçakta mı öleceğim?" diye sorar Yuriko: "Hayır bu uçakta değil" der. Wolverine'in gelecek hayatının bilgisine sahip olmadığı seyirciye ima edilir. Dünyanın geleceğine bilmek ve belirlemek yeteneği artık Yuriko temelinde Japonlardadır. Süper güçleri olan Yuriko'nun rüyasında gördügü her şey gerçekleşmiştir. Ancak tek bir istisna vardır; Wolverine'nin öleceğini görmesine rağmen Wolverine ölmez. Bu bağlamda geleceği değiştiren, dönüştüren ve kuran Wolverine temelinde Batı'nın gücüdür. Filmde Japonya'nın geleceği kurma gücü kısıtlı olarak sunulur.

Wolverine, Japonya'daki zehir ile ilk defa ölme noktasına gelir. Aynı şekilde filmin başında Japonya'da tutsak edilmiştir. Bu bağlamda Japonya Wolverine'ni yok etme gücü ve kudretine sahip yegâne yer olarak imlenir. Gücü tükenme noktasına gelen Wolverine, kötü Japonların saldırısından Mariko'nun yardımıyla kurtulur. Wolverine: "Daha önce yardıma ihtiyacı olmadığını" belirtiği hayatında yeni bir durum vardır; artık güçsüzdür, yardıma ihtiyaç duyar. Bu yardımı sağlayan ise Batılı oryantalist bakışın simgesi Japon Mariko'dir. Amerika'nın yükselmesi, dirilmesi, yeniden güçlenmesi ancak boyun eğen, geleneksel Japonya sayesinde olabilir. Aynı șekilde Mariko'nun anlattığı Japon hikâyesine göre "Kuzuri" adındaki canavar onları koruyacak güvenliklerini sağlayacaklardır, filmde bu zımnen Wolverine'dir. Geleneksel Japon hikâyesinde Wolverine belirtilerek üstü kapalı olarak Amerika'nın gücünün kurtarıcılığının Japonya'nın kaderi ve kaçınılmazı olduğu halk hikâyelerinde bile bulunduğu vurgulanır.

Filmde Japonlar iyi ve kötü olarak net çizgilerle ayrılmıştır; bu ayrım Wolverine'nin yanındakiler ve karşısındakiler temeline de dayanır. Mariko'nun babası kızını öldürmeye çalışan, bütün mirası almak isteyen, gözü para hırsı bürümüş olarak yansıtılır. Japonya'nın Adalet Bakanı ise hayat kadınları ile cinsel birliktelik yaşayan nişanlısını öldürtmek için mafya (Yakuzalar) ile anlaşan biridir. Japon olarak iyi olan kimseler ise atom bombasının ilk atıldığı Nagazaki de temsil edilir. Onun dışında özellikle büyük kentte Japon insanların olumlu temsiline pek rastlanılmaz. Wolverine, Mariko'nun babasını öldürmez ona: “Kendi kızını öldürmeye çalıștın bununla yaşa", der; bu davranış biçimi babayı harakiri yaparak kendisini öldürmeye zorlar. Diğer bir ifade ile Wolverine'nin istediği Mariko'nun babası temelinde Japonya'nın teknolojiden uzaklaşması ve geleneksel davranış biçimlerine geri dönmesidir.

Filmin başında güçlerini istemeyen ve ölmeyi isteyen Wolverine, Japon tehlikesi karşısında bu fikrinden vazgeçer. Dünyanın geleceği için Wolverine yaşamalı ve savaşmalıdır. Filmin sonunda ise Amerika'nın dünyanın geleceği için savaşmış olması meşrulaştırılır. Napier filmin sadece tekno-oryantalizmi öne çıkartmayıp 11 Eylül saldırıları ve Ortadoğu'daki başarısız politikalarının da bir yansıması olduğunu belirtilir. Wolverine filmi birçok sorunu çözmeye çalışıyor bunlar; Amerikan eril kimliğinin istikrarsızlaştırılması, 11 Eylül hadisesi ve Orta Doğu tarafından sarsılmış ancak Asya ekonomilerinin yükselişine derinden bağlı bir istikrarsızlașmadır (Napier, 2013). Batılı ülkeler, Doğu Asya ile kültürel ve ekonomik egemenlik için mücadele ederken tekno-oryantalizmi kendi arzuları ve korkuları için etkileyici bir araç olarak kullanırlar (Roh, Huang ve Niu, 2015, s. 3). Medya metinlerinde kötü, teknoloji ile psikolojilerini bozmuş Asyalı sunumu böylece Batılı zihni rahatlatır. Teknoloji yani nükleer bomba ile yok edilen Japonya, filmin sonunda teknoloji ile büyüyen ve teknolojinin en uç noktasında ölümsüzlüğü elde etme noktasına gelen Japonya'ya evrilir. Gittikçe gelişen Doğu Asya ülkelerinden Amerika temelinde Batı memnun 
değildir. Bu açıdan tekno-oryantalizm Batı'nın "oryantalizm paniği” olarak da adlandırır (Morley ve Robins, 1995, s. 160). Amerika, oryantalizm paniğini gidermek için ise sinemadaki süper kahramanlara başvurmaktadır. Bir süper kahraman ya da aksiyon filmi olarak üst katmanda değerlendirilecek eser zımni mesajlarında Amerika'nın Japonya'nın kötülügünü engelleyecek yegâne güç olduğunu vurgulayan bir evrene dönüşür.

\section{Sonuç}

Son yıllarda dijital dünyanın teknoloji temelli büyümesi yatırımlarını bu yönde kanalize eden Doğu Asya ülkelerinin ön plana çıkmasını sağlar. Bilgisayar işlemcileri, kamera ekipmanları, cep telefonu aletleri, elektrikli otomobiller, data depolama araçları, video oyun konsolları gibi birçok teknolojik yenilik Doğu Asya ülkelerinde üretilip dünyaya yayılmaktadır. Zamanında seyyahların, tarihçilerin, araştırmacıların roman, ansiklopedi ya da resim ile hayali Doğu imgesini yarattığı gibi günümüzde video oyunları, diziler ve filmler gerçekleștirmektedir. Said'in oryantalizm kavramlaştırmasından sonra Doğu ve Batı arasındaki ilişkiler güç ve iktidar ilişkilerine göre yeniden tanımlanır. Oryantalizm bir anlamda Doğu'nun zihin dünyasında Batı'nın gelişmiş, güçlü ve modern olma tasavvurudur. Batı toplumları özellikle kendileri ile ekonomik, siyasal ve teknolojik güç çekişmesine giren ülkeleri ya da toplumları, zihin dünyasında kötü, pasif ve alt düzeyde gösterme çabası içindedir. Tekno-oryantalist düşünce özellikle Amerika bağlamında Batı'nın hala güçlü olduğunu önce Doğu Asya ülkelerine daha sonra da bütün dünyaya ispat etme çabasıdır.

$X$-Men serisi filmler ve The Wolverine filmi hem Batı hem de Doğu dünyasında ilgiyle izlenen yapımlardır. Bir Hollywood filmi olarak The Wolverine, tekno-oryantalizm açısından ele alındığında eserin açık biçimde Japonya'nın teknolojik olarak ilerlemesinden korku duyan Batı bilinçaltının bir yansıması olduğu ortaya çıkmaktadır. Nagazaki ve Hiroşima'ya atılan atom bombası ile on binlerce insan ölmüş, sakat kalmış Japonya'da birçok yerleşim yeri harap hale gelmiştir. Film ele alındığında ise atom bombasının korkunç etkileri tümden göz ardı edilir hatta bunun ötesinde günümüz Hiroşima ve Nagazaki şehirleri mutlu insanlarla dolu mekânlar olarak sunulur.

Wolverine atom bombasından bir kiși de olsa kurtaran iyi Batılı imajı yüklenmektedir. Diğer yandan filmin simgeleştirmesinde Wolverine'nin Amerika'yı temsil ettiği düşünüldügünde bombalama sonucu tutsaklıktan kurtulan ve özgürlüğe kavuşan aslında Wolverine dolayısıyla Amerika'dır. Batı'nın özellikle Amerika Birleşik Devletleri'nin zihin dünyasında Japonya'nın atom bombasının intikamını alacağı fikri de tezahür eder. Öte yandan Wolverine'in atom bombasından kurtardığı tek kişinin daha sonra bütün dünyayı ele geçirmeye çalışan ölümsüz dev bir robot olma heveslisi Japon olması da manidardır. Diğer bir anlatımla atom bombasının atılması ve on binlerce insanın ölmesi gerekçelendirilir ve meşrulaştırılır. Böylece atom bombası atılmasa dünyayı yok edecek Japonların var olabileceği imajı oluşturulur. Japonları öldürmeseydik ileride kötü insanlar olabileceği fikri seyirciye zımnen iletilir. Filmin anlatısı savaş nedeniyle yıkıma uğramış kötü durumdaki Japonya ile teknolojinin ilerlediği günümüz Japonya'sı arasındaki farkı da betimlemektedir. Savaş sonrası kalkınan Japonya'ya kötümser, tekno-fobik bir ülke imajı hâkimdir. Filmde Amerika Birleşik Devletleri açısından geçmişte savaşılan ve galip gelinen Japonya ile teknolojik anlamda yakın gelecekte verilecek olan bir mücadelenin de yansımaları görülmektedir.

Filmin sonunda Mariko robot canavar Yashida'yı yani teknoloji olarak üstün Japonya'yı yener. Bu açıdan filmde kazanan temel olarak Batı'nın tanımladığı klasik oryantalist 
Japonya'nın simgesi olan Mariko'dur. Aynı zamanda bu, Japonya halkının geleneksel değerler ile teknolojik gelişme olmadan yașaması gerektiğini vurgulayan düşünce biçimidir. Batı'nın tekno-oryantalist söylemi Mariko gibi insanlar inşa etmek üzerine kuruludur. Dedesi temelinde robotik ruhsuz olarak imlenen Japonya Mariko'ya uygun değildir.

Geçmişte Avrupa günümüzde Amerika Birleşik Devletleri merkez ülkeler olarak dünyanın geri kalanına kendi ideolojilerini ve düşüncelerini yayar. Dünyanın büyük bir kısmının kendi fikirlerine göre yönlendirmeye çalışan Batılı ülkelerdir. Ancak günümüze gelindiğinde dünyanın çeşitli ülkelerinin kendi fikirlerine göre hareket etmeye çalıştığı görülmektedir. Tek kutuplu ya da iki kutuplu dünyanın dışında özellikle küreselleşmenin farklılaştırıcı özelliği sayesinde birçok ülke merkez, dominant Batılı ülkelerin görüş ve düşünceleri sorgulamaktadır.

Hollywood'un sinema sektöründe egemen yapım ve dağıtım sistemi ile aslında kendi ideolojisinin yayılmasını da kolaylaştırır. Amerika'nın hegemonyasına karşı sinema alanında Doğu Asya'da farklı duruşlar da görülmektedir. Ancak bunlar şu an için yetersiz görünmektedir. Örneğin Güney Kore yapımı 2020 yılında Oscarlarda birçok ödül alan Parazit filmi incelendiğinde filmin sonunda zengin aile Amerikan Yerlileri gibi giyinmişlerdir, çocuklarının isteği üzerine evlerinin bahçelerine Amerikan Yerli kabilelerin çadırlarından yaptırmışlardır. Şiddetli yağmurla evleri su bastığı bir günde çocukları bahçede çadırdayken, çadırın su geçirip geçirmeyeceği hakkında konuşurlar; evin annesi "çadırı Amerika'dan getirttiklerini tabii ki su geçirmeyeceğini” vurgular. Ayrıca annenin çocuklarına sürekli İngilizce öğretme isteği ve Amerika Birleşik Devletleri'nde eğitim görmüş öğretmen arzusu dikkat çekmektedir. Bu açıdan Parazit filmi bağlamında tekno-oryantalizmin yapmak istediği ne kadar gelişmiş, teknoloji ve refah seviyesi yüksek olursa olsun Batı'ya ve dolayısıyla Amerika'ya her zaman ihtiyaçları olduğu düşüncesi Asyalı insanların zihin dünyalarında yer ettiği görülür.

Sonuç olarak tekno-oryantalizm, kapitalizm ve emperyal düşüncelerle iç içedir. Bu açıdan kapitalizmin yayılmacı, genişlemeci hızı ve kâr odaklılı̆̆ı Japonya ve Doğu Asya ülkelerine avantaj sağlamaktadır. Aslında Amerika Birleşik Devletleri yükselen ve kendisini hem ekonomik hem de teknolojik ve siyasi olarak geçebilme potansiyeline sahip Japonya'dan ve Doğu Asya'dan çekinmektedir. Film teknolojik gelişmenin fazlasının da insanları ve ulusları kötü etkileyeceği fikri üzerine inşa edilmektedir. Ancak bu sadece Batı dışı toplumlar için geçerlidir; film özelinde ve Wolverine karakteri temelinde Batı teknolojik olarak ileri olsa bile ahlaken iyi kalabilmektedir. Tekno-oryantalist söylemler temel olarak öyle olmayan ama doğruymuş gibi yansıtılan hayali imajlardır. Bu hayali imajlar tekrar tekrar dolaşıma sokularak gerçek izlenimi yaratır. Filmde aslında Amerikan seyircisine Japonya ve Doğu Asyalıların teknolojik olarak ileride görülmesine karşın Amerika'nın gücüne, desteğine, bilgisine ve korumasına ihtiyacı olduğu vurgulanır. Bu filmlerde başta Japonya ve Kore olmak üzere Doğu-Asya ülkelerine Amerika Birleşik Devletleri koruyuculuğunda ekonomik, kültürel ve siyasi olarak güçlü olabileceğinin mesajı da iletilir.

\section{Notlar}

1 Tekno-oryantalizm değişik kavramlar ile de ifade edilmektedir. Bu bağlamda "dijital-oryantalizm" veya video, konsol, bilgisayar oyunları ile bağlantılı olarak "oyunsal oryantalizm" (gamic orientalism) kavramları kullanılmaktadır (Goto-Jones, 2015, s. 36). Chun ise yüksek teknolojili oryantalizm (high-tech orientalism) kavramını kullanmakta ve bunun sömürgecilik değil, küresel ekonomiye ve veri akışlarına paranoyakça bir tepki olduğunu ifade etmektedir (Chun, 2007). Diğer bir ifade ile "yüksek teknolojili oryantalizm" süreci görece olarak olumsuz bulmamaktadır. 


\section{Kaynakça}

https://boxofficeturkiye.com/.(2013,12 06). 02 5, 2020 tarihinde https://boxofficeturkiye. com/: https://boxofficeturkiye.com/yillik/?yil=2013\&yilop=tum adresinden alınd

https://www.boxofficemojo.com/. (2014). 02 05, 2020 tarihinde https://www. boxofficemojo.com/: https://www.boxofficemojo.com/year/world/2013/ adresinden alındı

Binark, M. (1998). Oryantalist Söylem ve Japonya Meiji Dönenıi (1868-1912) Japon Kadın Hareketi Tarihini Okumak. Kültür ve İletişim, 1(1), 65-90.

Boztemur, R. (2002). Marx Doğu Sorunu ve Oryantalizm. Doğu-Batı Dergisi (20/ Oryantalizm-I), 135-152.

Choe, S. ve Kim, S. Y. (2015). Never Stop Playing: StarCraft and Asian Gamer Death. D. Roh, B. Huang ve G. Niu içinde, Techno-Orientalism-Imagining Asia in Speculative Fiction, History, and Media (s. 113-124). New Jersey: Rutgers University Press.

Chun, W. H. (2007). Race and Software. M. T. Nguyen ve T. L. Tu içinde, Alien EncountersPopular Culture in Asian America (s. 305-334). London: Duke University Press.

Cornea, C. (2007). Science Fiction Cinema:Between Fantasy and Reality. Edinburgh : Edinburgh University Press.

Çırakman, A. (2002). Oryantalizmin Varsayımsal Temelleri:Fikri Sabit İmgelem ve Düşünce Tarihi. Doğu-Batı Dergisi (20/Oryantalizm-I), 181-198.

D’Angelo, W. (2020, 2 8). Switch vs PS4 vs Xbox One Global Lifetime Sales - January 2020. 3 16, 2020 tarihinde https://www.vgchartz.com/: https://www.vgchartz.com/ article/442352/switch-vs-ps4-vs-xbox-one-global-lifetime-salesjanuary-2020/ adresinden alındı

Dickenson, B. (2006). Hollywood's New Radicalism-War,Globalisation and The Movies From Reagan to George W. Bush. New York: I.B. Tauris\&Co. Ltd.

Goto-Jones, C. (2015). Playing with Being in Digital Asia: Gamic Orientalism and the Virtual Dōjō. Asiascape: Digital Asia, 2(1-2), 20-56.

Hough, K. (2015). Demon Courage and Dread Engines: America's Reaction to the RussoJapanese Invasion Sublime. D. Roh, B. Huang ve G. Niu içinde, Techno-Orientalism Imagining Asia in Speculative Fiction, History, and Media (s. 23-39). New Jersey: Rutgers University Press.

Ishii, D. (2015). Palimpsestic Orientalisms and Antiblackness;or, Joss Whedon's Grand Vision of an Asian/American Tomorrow. D. Roh, B. Huang ve G. Niu içinde, TechnoOrientalism-Imagining Asia in Speculative Fiction, History, and Media (s. 180-192). New Jersey: Rutgers University Press.

Jeong, K. (2011). Crisis of Gender and The Nation in Korean Literature and Cinema: Modernity Arrives Again. Maryland: Lexington Books.

Jones, J. (2015). Japan Removed: Godzilla Adaptations and Erasure of the Politics of Nuclear Experience. M. Edwards içinde, The Atomic Bomb in Japanese Cinema: Critical Essays (s. 34-55). North Carolina: McFarland\&Company Inc.

Kahraman, H. B. (2002). İçselleştirilmiş, Açık ve Gizli Oryantalizm ve Kemalizm. Doğu-Batı Dergisi (20/Oryantalizm-I), 153-180. 
Kellner, D. (2013). Sinema Savaşları Bush-Cheney Döneminde Hollywood Sineması ve Siyaset. (G. Koca, Çev.) İstanbul: Metis Yayınları.

Keyman, F. (2002). Globalleşme, Oryantalizm ve Öteki Sorunu: 11 Eylül Sonrası Dünya ve Adalet. Doğu-Batı Dergisi (20/Oryantalizm-II), 11-32.

Klein, C. (2003). Cold War Orientalism Asia in the Middlebrow Imagination 1945-1961. Los Angeles: University of California Press.

Klein, C. (2020). Cold War Cosmopolitanism:Period Style in 1950s Korean Cinema. Oakland: University of California Press.

Konty, O. (2002). Üçgenin Tabanım Yok Sayan Pythagoras: Oryantalizm ve Ataerkillik Üzerine. Doğu Batı Dergisi (20/Oryantalizm-I), 117-134.

Kosnik, A. D. (2015). The Mask of Fu Manchu, Son of Sinbad, and Star Wars IV:A New Hope: Techno-Orientalistof Twentieth-Century. D. Roh, B. Huang ve G. Niu içinde, TechnoOrientalism-Imagining Asia in Speculative Fiction, History, and Media (s. 89-100). New Jersey: Rutgers University Press.

Low, M. (2003). Displaying the future: techno-nationalism and the rise of the consumer in Postwar Japan. History and Technology, 19(3), 197-209.

Lozano-Méndez, A. (2010). Techno-Orientalism In East-Asian Contexts: Reiteration, Diversification, Adaptation. M. Telmissany ve S. T. Schwartz içinde, Counterpoints: Edward Said's Legacy (s. 185-210). Newcastle: Cambridge Scholars Publishing.

Marchart, O. (1998). The East, the West and the Rest: Central and Eastern Europe between Techno-Orientalism and the New Electronic Frontier. Convergence: The International Journal of Research into New Media Technologies, 4(2), 56-75.

McKay, D. (2017). Camera Men: Techno-orientalism in Two Acts. Journal of American Studies, 51(3), 939-964.

McLoad, K. (2013). Afro-Samurai:Techno-orientalism and Contemporary Hip-hop. Popular Music, 32(2), 259-275.

Morley, D. ve Robins, K. (1995). Spaces of Identity-Global Media,Electronic Landscapes and Cultural Boundaries. New York : Routledge.

Napier, S. J. (2013, 08 20). The Wolverines' Burden: Orientalism and the Superhero. 01 03, 2020 tarihinde https://www.huffpost.com/: https://www.huffpost.com/entry/ the-wolverines-burden-ori_b_3763815 adresinden alındı

Nguyen, M. T. ve Tu, T. L. (2007). Introduction. M. T. Nguyen ve T. L. Tu içinde, Alien Encounters-Popular Culture in Asian America (s. 1-34). London: Duke University Press.

Nihei, C. (2009). Thinking Outside the Chinese Box: David Mitchell and Murakami Haruki's Subversion of Stereotypes About Japan. New Voices, 3, 86-103.

Niu, G. A. (2008). Techno-Orientalism, Nanotechnology, Posthumans and Post-Posthumans in Neal Stephenson's and Linda Nagata's Science Fiction. Melus, 33(4), 73-96.

Özden, Z. (2004). Film Eleştirisi-Film Eleştirisinde Temel Yaklaşımlar ve Tür Filmi Eleştirisi. Ankara: İmge Kitabevi.

Park, J. C. (2010). Yellow Future Oriental Style in Hollywood Cinema. Minneapolis: University of Minnesota Press. 
Rivera, T. (2014). Do Asians Dream of Electric Shrieks?: Techno-Orientalism and Erotohistoriographic Masochism in Eidos Montreal's Deus Ex: Human Revolution. Amerasia Journal, 40(2), 67-86.

Roh, D., Huang, B. ve Niu, G. (2015). Technologizing Orientalism: An Introduction. D. Roh, B. Huang ve G. Niu içinde, Techno-Orientalism-Imagining Asia in Speculative Fiction, History, and Media (s. 1-22). New Jersey: Rutgers University Press.

Ryan, M. ve Kellner, D. (2010). Politik Kamere-Çağdaş Hollywood Sinemasının Ídeolojisi ve Politikası. (E. Özsayar, Çev.) İstanbul: Ayrıntı Yayınları.

Said, E. (1998). Oryantalizm. (N. Uzel, Çev.) İstanbul: İrfan Yayıncılık.

Sohn, S. H. (2008). Introduction:Alien/Asian:Imagining the Racialized Future. Melus, $33(4), 5-22$.

Soni, J. (2020, 1 31). Huawei phone sales beat Apple in 2019. 2 13, 2020 tarihinde https:// www.techradar.com/: https://www.techradar.com/news/huawei-phone-salesbeat-apple-in-2019 adresinden alındı

Suzuki, E. (2017). Beasts from the Deep. Journal of Asian American Studies, 20(1), 11-28.

Tzarina, P. ve Fung, C. (2015). How Does It Not Know What It Is: The Techno-Orientalized Body in Ridley Scott's Blade Runner and Larissa Lai's Automaton Biohraphies. D. Roh, B. Huang ve G. Niu içinde, Techno orientalism:Imagining Asia in Speculative Fiction, History and Media (s. 193-208). New Jersey: Rutgers University Press.

Ueno, T. (1999). Techno-Orientalism and Media-Tribalism:On Japanese Animation and Rave Culture. Third Text, 13(47), 95-106.

Ueno, T. (2002). Japanimation and Techno-Orientalism. B. Grenville içinde, The Uncanny: Experiments in Cyborg Culture (s. 223-231). Vancouver: Arsenal Pulp Press.

Wagenaar, W. (2016). Wacky Japan: A Mew Face of Orientalism. Asia in Focus(3), 46-54.

Woronoff, J. (1996). Japan as -anything but- Number One. London: MacMillan Press.

Yamashita, K. T. ve Pablo, L. M. (2017). Anime Wong:Mobilizing(techno) OrientalismArtistic Keynote and Conversation. Journal of Contemporary Drama in English, 5(1), 173-188.

Yavuz, H. (1998). Alafrangalı̆̆ın Tarihi. İstanbul: Timaş Yayınları.

Yeats, D. (2015). Home Is Where the War Is: Remaking Techno-Orientalist Militarism on the Homefront. D. Roh, B. Huang ve G. Niu içinde, Techno-Orientalism-Imagining Asia in Speculative Fiction, History, and Media (s. 125-138). New Jersey: Rutgers University Press.

Yılmaz, E. (2008). Sinema ve İdeoloji İlişkileri Üzerine. B. Bakır, Y. Ünal ve S. Saliji içinde, Sinema, Ídeoloji, Politika Sinemasal Yazılar 1 (s. 63-86). Ankara: Orient Yayıncılık.

Yu, T. (2008). Postmodern Futures: Naked Lunch, Blade Runner and Neuromancer. Melus, $33(4), 45-71$. 


\title{
An Analysis of The Wolverine (2013) in terms of Techno-Orientalism
}

\author{
Rifat Becerikli (Asst. Prof. Dr.)
}

\section{Extended Abstract}

The country or countries, which are politically and economically in a difficult situation, try to ensure their citizens to act and join together by creating an imaginary enemy, a problem. The USA aims to eliminate the political and economic problems, which is particularly experienced in the 2000s, by marginalizing East Asian countries. In this respect, orientalist elements always point out the power relations. In recent years, East Asian countries, which invest in technology, have become prominent due to technologybased growth of the digital world. Many technological innovations such as computer processors, camera equipment, mobile phone tools, electric cars, data storage devices, video game consoles are produced in East Asian countries and distributed to the world. The fundamental grounds of Techno-orientalism are based on Edward Said's conceptualization of orientalism. It demonstrates a new technology-based viewpoint such as social media, computer games, Internet, cyber networks in power relations that lasted centuries between the West and the East. In this sense, it is more appropriate to regard Said's opinions as classical orientalism in a basic context. Techno-orientalism is also a way of thinking that indicates the political attitudes of East Asian countries for their own interests due to the political and economic concerns of the West. Techno-orientalism is also an expression of the West's failure to manage East Asia via hegemony. However, techno-orientalism can also be considered as a preliminary preparation by the West to manage East Asian countries in the future.

After Said's conceptualization of orientalism, the relations between the East and the West are redefined according to power forms. Orientalism is, in a sense, an advanced, powerful and modern imagination of the West in the mind of the East. Techno-orientalist thinking is an effort to prove that the West is still strong, particularly in the context of America, to East Asian countries and then to the entire world. One of the most significant elements of this is the films that are one of the most effective mass media. Video games, movies produce the same in today's world as travelers, historians, researchers create the imaginary image of the East with novels, encyclopedia or painting. For example, the first Japanese-made Godzilla (1954) movie symbolizes a monster caused by America's nuclear bombs in World War II. In this context, it also has a critical attitude. However, later in Hollywood-made re-makes, there was the image of the world that got rid of the Godzilla thanks to the American army. In this respect, the American cinema sector has made incidents appropriate for their Western minds for a long time. The aim of the study is to analyze X-Men: The Wolverine (2013) in terms of techno-orientalism which is not studied in the social sciences much in Turkish literature. Techno-orientalism is often encountered in sci-fi and cyberpunk movies. In this context, the universe of the study is particularly technology-based Hollywood science fiction movies. The reason for selecting The Wolverine as a sample is the use of a known character from the X-Men series by the cinema audience. In orientalism or techno-orientalism, it is aimed to create an imaginary order or the perception of the "other". Basically, human thought is desired to be directed. Mainstream Hollywood films such as Wolverine, which can be regarded as X-Men series films, are productions that attract more audience. In this respect, the audience, who go 
to the cinema, at least increases the chance of being affected by the dominant thought in terms of the discourse of the film. In the narrative of the film, an attempt to dehistoricize is remarkable. The points of why Wolverine was captured in Japan and why Japan was bombed are not emphasized in the narrative. Western societies particularly try to show the countries or societies, which are in economic, political and technological power conflicts with themselves, bad, passive and degraded in their minds. Since Edward Said's conceptualization of orientalism, hegemonic effects of the West on Eastern societies has begun to be studied more in books, films and media texts.

The X-Men series and the Wolverine are productions that are watched with interest in the Western and Eastern worlds. As a Hollywood movie, The Wolverine turns out to be a reflection of the Western subconscious, which clearly fears of the technological development of Japan, when it is handled in terms of techno-orientalism. With the atomic bomb dropped on Nagasaki and Hiroshima, tens of thousands of people died and become permanently disabled, and several settlements in Japan were devastated. When the film is examined, the terrible effects of the atomic bomb are completely ignored, and beyond that, present-day Hiroshima and Nagasaki cities are presented as a place full of happy people.

The good Western image, which saves a person from atomic bomb, albeit one, is attributed to the Wolverine. On the other hand, Wolverine is considered to represent America in the symbolization of the film, Wolverine, who survived captivity and liberated because of the bombing, is indirectly America. The idea, which Japan will take revenge on atomic bomb, appears particularly in the mind of the United States. On the other hand, it is meaningful that the only person Wolverine saved from the atomic bomb was the Japanese, who was eager to become an immortal giant robot that later tried to take over the whole world. In other words, dropping an atomic bomb and deaths of tens of thousands of people are legitimated and justified. Therefore, the image of the Japanese, who would destroy the world, is created if the atomic bomb was not dropped. The idea, which they would have been bad people in the future if we had not killed the Japanese people, is implicitly conveyed to the audience. It is seen that several countries of the world are trying to act according to their own opinions. Outside of the unipolar or bipolar world, many countries question the views and thoughts of the dominant Western countries, particularly thanks to the differentiating feature of globalization. Hollywood's dominant production and distribution system in the movie industry actually facilitates the spread of its own ideology. However, in the field of cinema, there have also been stances in East Asia against America's hegemony recently. When the film, Parasite, which was awarded many awards in the Oscars of South Korea in 2020, was examined, at the end of the film, the rich family was dressed like American Indians, and they set up the tents of the American Indian tribes in the gardens at their children's request. On a night when their house is flooded with heavy rain, the family talks about whether the tent will be waterproof while their children are in the tent. The woman of the house emphasizes that they brought the tent from America, of course, it would not be waterproof. In addition, it is seen that the upper class family imitates America in terms of language, culture and lifestyle. No matter how developed and the high level of technology and prosperity they have, techno-orientalism wants to remind them the idea that they always need the West and therefore America. In the context of the Parasite, it is also revealed that some people in South Korea are badly affected by techno-orientalism. Techno-orientalism communes with capitalist and imperial thoughts. In this respect, the expansionary speed and profit focus of capitalism 
provide advantages to Japan and East Asian countries. The film is built on the idea that much of technological development will affect people and nations badly. However, this is valid only to non-Western societies; even if the West is technologically developed in terms of the film and based on the character of Wolverine, it can remain morally good. Technoorientalist discourses are not basically true but they are imaginary images reflected as if they were true. These imaginary images circulate repeatedly, and create the real impression. In the film, it is emphasized to the American audience that they need power, support, knowledge and protection of America although Japan and East Asians are seen technologically developed. The narrative of the film also depicts the difference between Japan, which has been devastated due to war, and Japan that technology is developing. The image of a pessimistic techno-phobic country prevails in post-war Japan. The reflections of a new technological struggle with Japan, which was fought and defeated in the past, in the near future are seen in the film. At the end of the movie, Mariko defeats the robot monster Yashida, the technology-superior Japan. In this respect, the winner in the film is Mariko who is the symbol of the classical orientalist Japan defined by the West. It is also the way of thinking to emphasize that the Japanese people must live with traditional values without technological development. The techno-orientalist discourse of the West is based on creating people like Mariko. Japan, marked as a robotic and soulless on the basis of hier grandfather, is not suitable for Mariko.

As a result, in the past Europe, today the United States spread its own ideologies and thoughts to the rest of the world as central countries. It is the Western countries that try to direct most of the world according to their own ideas. The work, which is examined on the top layer as a superhero or action movie, turns into a universe to emphasize in its implicit messages that America is the only power to prevent the evil of Japan.

Keywords: Cinema, Techno-Orientalism, Orientalism, Hollywood Movies. 